\title{
Anxiolytic Effects of Quercetin: Involvement of GABAergic System
}

\author{
Ji Wook Jung ${ }^{1}$ and Seungheon Lee ${ }^{2 *}$ \\ ${ }^{1}$ Department of Herbal Medicinal Pharmacology, College of Herbal Bio-industry, Daegu Haany University, Gyeongsan 712-715, Korea \\ ${ }^{2}$ Department of Marine Life Sciences, School of Marine Biomedical Sciences, Jgiu National University, Jgiu 690-756, Korea
}

Received February 14, 2014 /Revised March 14, 2014 /Accepted March 17, 2014

\begin{abstract}
The present experiment investigated putative anxiolytic-like effects of quercetin using an elevated plus-maze (EPM) and hole-board apparatus test in mice. Quercetin is a flavonoid widely distributed in nature. Quercetin $(1.25,2.5,5$, or $10 \mathrm{mg} / \mathrm{kg}$ ) was orally administered to ICR mice $1 \mathrm{~h}$ before a behavioral evaluation in the EPM. Control mice were treated with an equal volume of vehicle, and positive control mice were treated with buspirone $(2 \mathrm{mg} / \mathrm{kg}$, i.p.). The mice administered quercetin (5 $\mathrm{mg} / \mathrm{kg}$ ) spent a significantly longer percentage of time in the open arms of the EPM and their percentage of entries into the open arms was significantly increased compared to the vehicle-treated controls $(p<0.05)$. The anxiolytic-like activities of quercetin were antagonized by trans-4-aminocrotonic acid (a GABA $A_{A-\rho}$ agonist, $20 \mathrm{mg} / \mathrm{kg}$ ) but not by flumazenil (a GABA $\mathrm{A}_{\mathrm{A}}$ antagonist, $10 \mathrm{mg} / \mathrm{kg}$ ) or WAY100635 (a 5-HT $1 \mathrm{~A}$ antagonist, $0.3 \mathrm{mg} / \mathrm{kg}$ ). Moreover, there were no changes in the locomotor activity or myorelaxant effects in any group compared with the vehicle-treated controls. In the hole-board apparatus test, the number of head-dips increased significantly in the single treatment with quercetin $(5 \mathrm{mg} / \mathrm{kg})$ group compared to the vehicle-treated controls $(p<0.05)$. These findings suggest that quercetin can promote anxiolytic-like activity, mediated by the GABAergic nervous system, in mice.
\end{abstract}

Key words : Anxiety, $\mathrm{GABA}_{\mathrm{A}-\mathrm{p}}$, mice, quercetin, trans-4-aminocrotonic acid

\section{Introduction}

Anxiety is broadly defined as a state of unwarranted or inappropriate worry, often accompanied by restlessness, tension, distraction, irritability, and sleep disturbances. This disproportionate response to environmental stimuli can hyperactivate the hypothalamic - pituitary - adrenal axis and the autonomic nervous system, resulting in the somatic manifestations of anxiety, including shortness of breath, sweating, nausea, rapid heartbeat, and elevated blood pressure. The Diagnostic and Statistical Manual of Mental Disorders, Fourth Edition has classified anxiety disorders into multiple distinct conditions, including generalized anxiety disorder, acute stress disorder, obsessive-compulsive disorder, panic disorder, posttraumatic stress disorder, social and other specific phobias alone or in combination with the above disorders, as well as substance-induced anxiety disorders. Generalized anxiety disorder is the most common

\footnotetext{
*Corresponding author

Tel : +82-64-754-3476, Fax : +82-64-756-3493

E-mail : slee76@jejunu.ac.kr

This is an Open-Access article distributed under the terms of the Creative Commons Attribution Non-Commercial License (http://creativecommons.org/licenses/by-nc/3.0) which permits unrestricted non-commercial use, distribution, and reproduction in any medium, provided the original work is properly cited.
}

of the anxiety disorders, with a lifetime prevalence of approximately $5 \%$ of the population in the United States [28] [28]. Therefore, anxiety disorders represent not only a significant public health issue, but place a substantial economic burden on society.

While definitive pathophysiological mechanisms have not yet been determined, anxiety symptoms and the resulting disorders are thought to be due to disrupted modulation within the central nervous system. Physical and emotional manifestations of this dysregulation are the result of heightened sympathetic arousal of varying degrees. Several neurotransmitter systems have been implicated to have a role in one or several of the modulatory steps involved. The most commonly considered are the serotonergic and noradrenergic neurotransmitter systems. In very general terms, it is thought that an underactivation of the serotonergic system and an overactivation of the noradrenergic system are involved. These systems regulated by other pathways and neuronal circuits in various regions of the brain, resulting in dysregulation of physiological arousal and the emotional experience of this arousal . Disruption of the gamma-aminobutyric acid (GABA) system has also been implicated because of the response of many of the anxiety spectrum disorders to treatment with benzodiazepines. More recently there has been some interest in the role of corticosteroid reg- 
ulation and its relationship to symptoms of fear and anxiety Corticosteroids may increase or decrease the activity of certain neural pathways, affecting not only behavior under stress, but also the brain processing of fear-inducing stimuli.

Quercetin, a flavonol, is a plant-derived flavonoid found in fruits, vegetables, leaves and grains. This bioflavonoid found in a variety of daily foods such as grapes, onions, and tea has increased in popularity because it is a highly studied, multidimensional, bioactive compound that possesses both antioxidant properties and the ability to modulate signal transduction pathways, leading to prevention and inhibition of many inflammatory reactions.

The purpose of this study was to investigate whether quercetin has anxiolytic-like activities. The elevated plusmaze test (EPM) and hole-board test were applied because it has been used to examine anxiolytic-like effects.

\section{Materials and Methods}

\section{Materials}

Quercetin, buspirone, WAY 100635, flumazenil and trans4-aminocrotonic acid (TACA) were obtained from SigmaAldrich (St. Louis, MO). All other materials were of the highest grade and were obtained from standard commercial sources.

\section{Animals}

Male ICR mice, weighing 25-30 g, were purchased from the Orient Co., Ltd. of the Charles River branch (Seoul, Korea). The animals were housed 5 or 6 per cage, allowed access to water and food ad libitum, and maintained under a constant temperature $\left(23 \pm 1^{\circ} \mathrm{C}\right)$ and humidity $(60 \pm 10 \%)$ under a 12-h light/ dark cycle (light on 07.30-19.30 hr). Animal treatment and maintenance were carried out in accordance with the Principle of Laboratory Animal Care (NIH publication No. 85-23, revised 1985) and the Animal Care and Use Guidelines of Daegu Haany University, Korea.

\section{Drug administration}

The mice were randomly divided into vehicle- or quercetin-treated groups. Quercetin suspended in 10\% Tween 80 solution was orally administered $1 \mathrm{hr}$ before behavioral tests. Concomitant with the quercetin-treated groups, a control group was given an aqueous suspension of $10 \%$ Tween 80 solution. Diazepam or buspirone, positive control, were dissolved in saline and were administered $30 \mathrm{~min}$ before the test. For antagonism tests, flumazenil suspended with a $10 \%$ (v/v) aqueous solution of Tween-80 or WAY 100635 dissolved in saline were intraperitoneally treated $30 \mathrm{~min}$ before the test.

\section{Locomotor activity in the open field test}

Testing was conducted in clear black Plexiglas boxes $(40 \times 40 \times 40 \mathrm{~cm})$ equipped with the video-based Ethovision System (Noldus, Wageningen, The Netherlands). The mice were placed in the center of the apparatus to evaluate horizontal locomotor activity $1 \mathrm{hr}$ after being treated with quercetin $(1.25,2.5,5$ and $10 \mathrm{mg} / \mathrm{kg})$ and video-recorded for 5 $\mathrm{min}$. The horizontal locomotor activity is expressed in terms of the total ambulatory distance and the frequency of rearing

\section{Elevated plus-maze test}

The EPM for mice consisted of two perpendicular open arms $(30 \times 7 \mathrm{~cm})$ and two enclosed arms $(30 \times 7 \mathrm{~cm})$ with 20 $\mathrm{cm}$ high walls, extending from the central platform $(7 \times 7 \mathrm{~cm})$. The open and closed arms were connected by a central square, $7 \times 7 \mathrm{~cm}$, to give an apparatus of a plus sign appearance. The floor and walls of the maze were constructed from the dark opaque polyvinylplastic plates. The maze was raised to a height of $50 \mathrm{~cm}$ above the floor level in a dimly lit room (40 Lux) and a video camera was suspended above the maze to record the movements for analysis $[15,19]$. Each mouse was placed at the center of the platform, its head facing an open arm. The animals were tested individually and only once for $5 \mathrm{~min}$. The maze was cleaned after each trial so as to remove any residue or odors. The following measurements were taken and analyzed using the video-based Ethovision System: the number of entries into the open or closed arms, the time spent in each arm, and the total distance moved in the EPM. All the experiments were carried out between 10:00 and 16:00 o'clock. One hour after the quercetin administration $(1.25,2.5,5$ or $10 \mathrm{mg} / \mathrm{kg}$, p.o.), the mice were placed in the EPM. The mice in the control group were given the vehicle solvent only, and the animals were tested individually once only for $5 \mathrm{~min}$. In a separate antagonism study, the mice were subjected to the co-administration of quercetin $(5 \mathrm{mg} / \mathrm{kg}$, p.o.) and either WAY 100635 (0.3 mg/kg, i.p.), flumazenil (10 mg/kg, i.p.), TACA $(20 \mathrm{mg} / \mathrm{kg}$ ) or $1 \mathrm{hr}$ and $30 \mathrm{~min}$ prior to testing, respectively. The mice were treated with buspirone $(2 \mathrm{mg} / \mathrm{kg}$, i.p.) $30 \mathrm{~min}$ before EPM test and used as the positive controls. 


\section{Hole-board test}

The hole-board apparatus (Ugo Basile, Italy) consisted of gray Perspex panels $(40 \times 40 \mathrm{~cm}, 2.2 \mathrm{~cm}$ thick) with 16 equidistant holes $3 \mathrm{~cm}$ in diameter in the floor. Photocells below the surface of the holes measured the number of head-dips. The board was positioned $15 \mathrm{~cm}$ above a table. The method was adapted from [25]. Mice were transported to the dimly lit laboratory at least $1 \mathrm{hr}$ before testing. Each animal was individually placed singly in the center of the board facing away from the observer and its behavior was recorded for $5 \mathrm{~min}$. The number of head-dips was recorded. Mice were orally administered quercetin $(1.25,2.5,5$ or $10 \mathrm{mg} / \mathrm{kg}$, p.o.) $1 \mathrm{hr}$ prior to the testing.

\section{Horizontal wire test}

A horizontal wire test was carried out by treating the mice with according to a slight modification of the method reported by Bonett et al [4]. Briefly, the mice were lifted by the tail and allowed to grasp a horizontally strung wire (1 $\mathrm{mm}$ diameter, $15 \mathrm{~cm}$ long and placed $20 \mathrm{~cm}$ above the table) with their forepaws, after which they were then released. The number of mice from each treatment group that did not grasp the wire with their forepaws or actively grasped the wire with at least one hind paw within a $10 \mathrm{sec}$ period was recorded. A myorelaxant drug would impair the ability of the mice to grasp the wire, and muscle relaxation is commonly associated with sedation. Quercetin $(1.25,2.5,5$ or $10 \mathrm{mg} / \mathrm{kg}$, p.o.) was administered $1 \mathrm{hr}$ before the horizontal wire test, or diazepam ( 1 or $5 \mathrm{mg} / \mathrm{kg}$, i.p.), a positive control, was administered $30 \mathrm{~min}$ before the test.

\section{Statistical analysis}

Values are expressed as the mean \pm S.E.M. Data were analysed by a one-way analysis of variance (ANOVA) followed by the Student Newman-Keuls test for multiple comparisons. For the antagonism study, the interactions between the agonist and antagonist were analysed separately with a two-way ANOVA [factors: agonist versus antagonist]; pairwise comparisons for the assessment of the antagonist influence on the agonist effects were conducted by using Tukey's test. Statistical significance was set at $p<0.05$.

\section{Results and Discussion}

\section{Effect of quercetin treatment in the EPM}

The percentage of time spent in the open arms and of entries into open arms was significantly increased in the quercetin-treated mice $(5 \mathrm{mg} / \mathrm{kg})$ compared with vehicletreated group $(45.5 \pm 4.1 \%$ versus $28.6 \pm 2.2 \%, 52.4 \pm 1.8 \%$ versus $39.5 \pm 2.7 \%$, Fig. $1 ; p<0.05)$. However, no significant change was observed in terms of the percentages time spent in open arms and of entries into open arms at the other doses of quercetin. In buspirone-treated $(2 \mathrm{mg} / \mathrm{kg}$ ) group, as a positive control, the percentages of time spent in open arms and entries into the open arms were significantly increased compared with the vehicle-treated group $(43.1 \pm 7.5 \%$ or 49.2 \pm 5.8 , Fig. 1; $p<0.05$ ). Thereafter, we adopted $5 \mathrm{mg} / \mathrm{kg}$ dose for further studies.

\section{Effect of quercetin treatment in Hole-board test}

The effect of quercetin on the changes in head-dipping behavior in mice is shown in Fig. 2. quercetin-treated mice manifested significant increases in the number of head-dips at dose of $5 \mathrm{mg} / \mathrm{kg}(88.3 \pm 1.6$ versus $71.8 \pm 1.8 \%$, Fig. 2; $p<0.05)$. However, there were no significant increases at the other doses of quercetin.

Effect of WAY-100635, flumazenil or trans-4aminocrotonic acid, on the anxiolytic-like activity of quercetin

In order to determine which nervous system is involved in the anxiolytic effect of quercetin, the quercetin $(5 \mathrm{mg} / \mathrm{kg}$ )

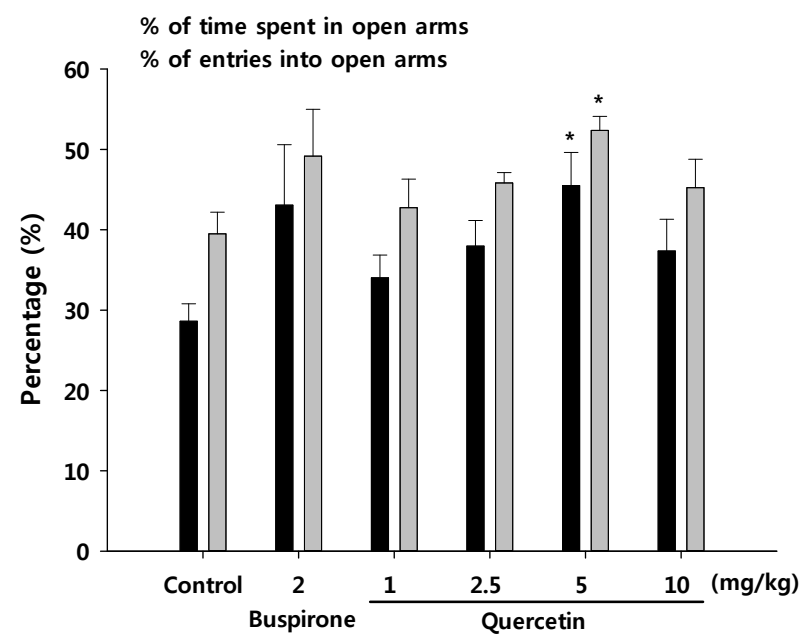

Fig. 1. Effect of quercetin on the percentage of the time spent in and the number of entries into the open arms of the elevated plus-maze over a $5 \mathrm{~min}$ test period in the mice. Mice were administered quercetin $(1.25,2.5,5$ or 10 $\mathrm{mg} / \mathrm{kg}$, p.o.). Each bar represents mean \pm S.E.M. of $10-12$ mice. $\mathrm{P}$ values for the group comparisons were obtained by one way ANOVA followed by Student-NewmanKeuls test $\left({ }^{*} p<0.05\right.$ as compared with the saline-treated control group). 


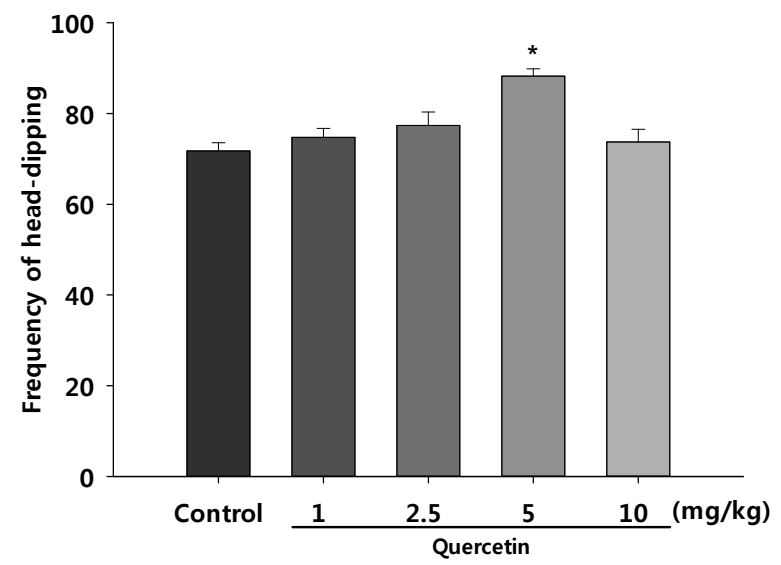

Fig. 2. Effects of quercetin on the changes in head-dipping behaviors in mice tested on the hole-board. Mice were administered quercetin $(1.25,2.5,5$ or $10 \mathrm{mg} / \mathrm{kg}$, p.o.). Each bar represents the mean \pm S.E.M. of 10 mice. P values for group comparisons were obtained by one way ANOVA followed by Student Newman-Keuls test $\left({ }^{*} p<0.05\right.$ versus the saline- treated control).

treated mice were subjected to a co-treatment with either WAY-100635, a 5- $\mathrm{HT}_{1 \mathrm{~A}}$ receptor antagonist, flumazenil, a $\mathrm{GABA}_{\mathrm{A}}$ receptor antagonist. As shown in Fig. 3, the anx-

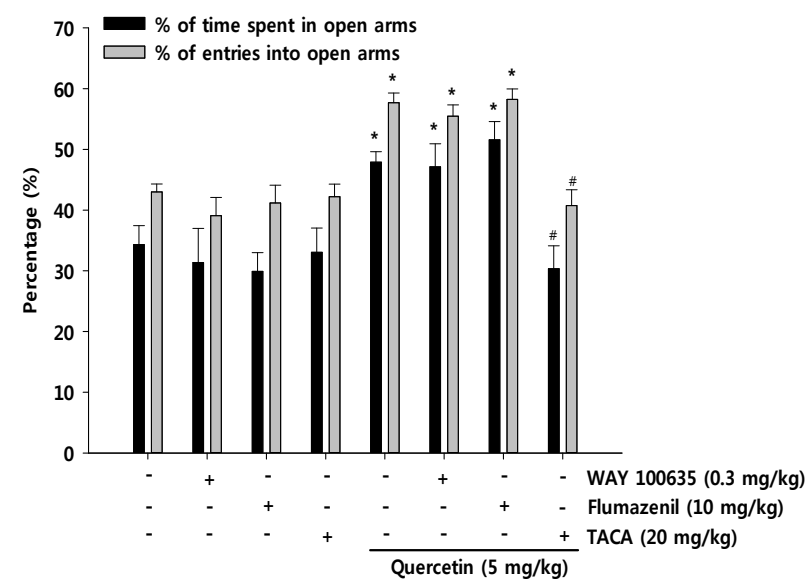

Fig. 3. Anxiolytic-like effect of quercetin was blocked by trans4-aminocrotonic acid (TACA) but not by WAY 100635 or flumazenil. The data is expressed as the mean $( \pm$ S.E.M.) of the percentage of the time spent in and the number of entries into the open arms of the elevated plus-maze, $1 \mathrm{hr}$ after the oral administration of qurecetin $(5 \mathrm{mg} / \mathrm{kg})$, qurecetin $(5 \mathrm{mg} / \mathrm{kg})+$ TACA $(20 \mathrm{mg} / \mathrm{kg})$, WAY $100635(0.3 \mathrm{mg} / \mathrm{kg})$ or flumazenil $(10 \mathrm{mg} / \mathrm{kg})(30$ min prior testing, i.p.), or vehicle; $\mathrm{N}=8-10$ mice per group. $\mathrm{P}$ values for the group comparisons were obtained by two way ANOVA followed by Student Newman-Keuls test $\left({ }^{*} p<0.05\right.$ versus the saline-treated control, \# $p<0.05$ as compared with the quercetin-administrated group). iolytic-like effects of quercetin were not antagonized either by WAY-100635 $(0.3 \mathrm{mg} / \mathrm{kg})$ or flumazenil $(10 \mathrm{mg} / \mathrm{kg})$. However, interestingly, the anxiolytic-like effects of quercetin $(5 \mathrm{mg} / \mathrm{kg})$ were blocked by TACA $(20 \mathrm{mg} / \mathrm{kg})$, a $\mathrm{GABA}_{\mathrm{A}-\mathrm{p}}$ receptor potent agonist.

\section{Effect of quercetin on the locomotor activity test and Horizontal wire test}

To differentiate between the possible stimulatory and false-positive effects of tested drugs on the modulation of exploratory behavior, a locomotor activity test was performed. However, as summarized in Table 1, no alterations in locomotor activity or rearing frequencies were observed in mice administered quercetin with the doses of 1.25 , $2.5,5$ or $10 \mathrm{mg} / \mathrm{kg}$ in the open-field test compared with vehicle-treated animals. Moreover, at $5 \mathrm{mg} / \mathrm{kg}$, diazepam significantly decreased the percentage of mice grasping the wire. In contrast, quercetin $(1.25,2.5,5$ or $10 \mathrm{mg} / \mathrm{kg}) \mathrm{did}$ not compromise the mice grasping the wire compared with vehicle-treated control group, indicating a lack of myorelaxation at these doses (Fig. 4).

The main findings of this study are that the administration of quercetin significantly increases the time spent in the open arms and the frequency of open arm entries in the EPM test, and that these effects were blocked by TACA, thus demonstrating GABAnergic nervous system involvement. In addition, no changes in spontaneous locomotor activities or myorelaxant effects were observed. Therefore, we suggest that quercetin has an anxiolytic-like effect due to $\mathrm{GABA}_{\mathrm{A}-\mathrm{p}}$ receptor activation, no obvious adverse effects, and in particular, no myorelaxant effect.

Table 1. Locomotor activity effects of quercetin on open field test in mice

\begin{tabular}{lc}
\hline & Total movement distance $(\mathrm{cm} / 5 \mathrm{~min})$ \\
\hline Control & $2332.0 \pm 153.3$ \\
Quercetin & \\
$1.25 \mathrm{mg} / \mathrm{kg}$ & $2456.6 \pm 91.1$ \\
$2.5 \mathrm{mg} / \mathrm{kg}$ & $2398.0 \pm 67.3$ \\
$5 \mathrm{mg} / \mathrm{kg}$ & $2534.6 \pm 53.7$ \\
$10 \mathrm{mg} / \mathrm{kg}$ & $2261.7 \pm 126.7$ \\
\hline
\end{tabular}

Spontaneous locomotor behaviour was measured in the open-field test for $5 \mathrm{~min}$ as described in the Materials and methods. Animals were orally treated with quercetin $(1.25,2.5$, 5 or $10 \mathrm{mg} / \mathrm{kg}$, po) $1 \mathrm{hr}$ before the test. Control animals were treated with the same volume of vehicle. Data are expressed as the means \pm S.E.M. ( $\mathrm{n}=9-10 /$ group). 


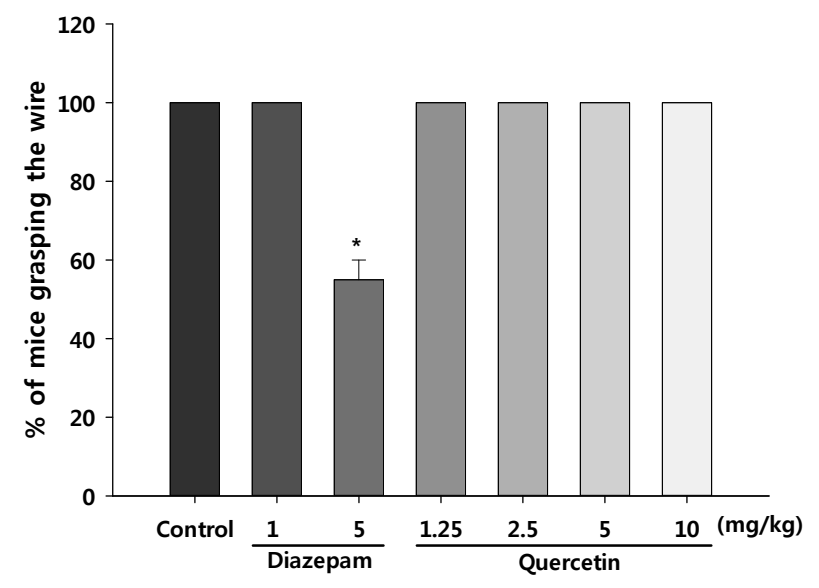

Fig. 4. Performance of mice in the horizontal wire test $1 \mathrm{~h}$ after oral administration of control, diazepam (1 and 5 $\mathrm{mg} / \mathrm{kg})$, or quercetin $(1.25,2.5,5$ or $10 \mathrm{mg} . \mathrm{kg})$. Data represent percentage of mice grasping the wire after administration of MAL. Each bar represents the mean \pm S.E.M. of 10 mice. $\mathrm{P}$ values for group comparisons were obtained by one way ANOVA followed by Student Newman-Keuls test $\left({ }^{*} p<0.05\right.$ versus the saline- treated control).

An anxiolytic agent increases the frequency of entries into the open arms and increases the time spent in open arms of the EPM. The EPM is considered to be an etiologically valid behavioral test of anxiety because it uses natural stimuli, such as a fear of a new, brightly lit open space and a fear of balancing on a relatively narrow raised surface. In this study, the buspirone treatment prolonged the percentage of open arm entries and time spent in the open arms (Fig. 1). The quercetin treatment also prolonged the percentage of time spent in the open arms as well as the percentage of open arm entries without altering the spontaneous behavior at the chosen dose regimen. The total distances of movement on the EPM were also unchanged by the quercetin treatment versus the vehicle controls (data not shown). In the hole-board test, the number of head-dips was dose-dependently increased by quercetin treatment (Fig. 2). In addition, no significant myorelaxant effect was observed after administering the quercetin in the horizontal wire test (Fig. 4). These observations suggest that the anxiolytic-like effect of quercetin is selective, and not the result of either a general stimulation of the locomotor activity or an exploratory behavior consequent to exposure to a novel environment.

Quercetin is a plant-derived flavonol found in fruits, vegetables, leaves and grains. This bioflavonoid found in a variety of daily foods such as grapes, onions, and tea has increased in popularity because it is a highly studied, multi- dimensional, bioactive compound that possesses both antioxidant properties and the ability to modulate signal transduction pathways, leading to prevention and inhibition of many inflammatory reactions . Recent evidences suggest that quercetin reverses the behavioral and biochemical effects produced by stress $[2,26]$. Moreover, Bhutada et al [3] reported that quercetin produces anxiolytic-like effects probably through modulation of CRF.

GABA is the primary inhibitory neurotransmitter in the central nervous system (CNS). One third of all CNS neurons are thought to be GABAergic. GABA is present in relatively high concentrations in the spinal cord and in all regions of the brain but does not exist in neurons outside the CNS. The intrinsic inhibitory signal of GABA is transduced by a family of synaptic and extrasynaptic hetero-oligomeric proteins referred to as the $\mathrm{GABA}_{\mathrm{A}}$ receptors. The prototypic anxiolytic drugs, benzodiazepines, are considered to produce their anxiolytic effects by facilitating the action of GABA at the $\mathrm{GABA}_{\mathrm{A}}$-benzodiazepine receptor complex and, in addition, $G_{A B A_{A}}$ receptor agonists like muscimol and $\mathrm{GABA}_{\mathrm{A}}$ receptor antagonists like picrotoxin and bicuculline have been shown to possess anxiolytic and anxiogenic properties, respectively, in the elevated plus maze.

$\mathrm{GABA}_{\mathrm{A}-\mathrm{p}}$ receptors differ from other members of the $\mathrm{GABA}_{\mathrm{A}}$ receptor family in both composition of subunit and functional properties have been recently obtained [11]. $\mathrm{GABA}_{\mathrm{A}-\rho}$ receptors are ligand-gated $\mathrm{Cl}^{-}$channels formed by homo-oligomeric and hetero-oligomeric assembly of $\mathrm{GABA}_{\mathrm{A} \text { - }}$ $\rho$ subunits that are insensitive to the $\mathrm{GABA}_{A}$ antagonist bicuculline, and to baclofen, a $\mathrm{GABA}_{B}$ receptor agonist $[6,18]$ but selectively blocked by (1,2,5,6-tetrahydropyridine-4-yl) methylphosphinic acid, a compound specifically designed to block the $\mathrm{GABA}_{\mathrm{A}-\mathrm{p}}$ receptor . Moreover, [11] demonstrated that $\mathrm{GABA}_{\mathrm{A}-\mathrm{p}}$ receptors may have a role in the amygdaloid modulation of fear and anxiety. In the present study, the anxiolytic effect of quercetin was blocked by co-treatment with TACA. Although TACA is a dual agonist for $\mathrm{GABA}_{A}$ and $\mathrm{GABA}_{\mathrm{A}-\mathrm{p}}$ receptors, these results suggest that quercetin exert its anxiolytic effect through $\mathrm{GABA}_{\mathrm{A}-\mathrm{p}}$ receptors since $\mathrm{GABA}_{\mathrm{A}}$ receptor blockade failed to block the effect of quercetin (Fig. 3).

In the present study, the exact reasons why the higher dose of quercetin $(10 \mathrm{mg} / \mathrm{kg})$ was less effective than that of lower dose $(5 \mathrm{mg} / \mathrm{kg})$ are unclear. However, it could be speculated that these phenomena were observed because of autoreceptor of any neurotransmitters. Similar bell-shaped 
dose-response curves have been reported after psychiatric treatment such as buspirone, cannabidiol and etc [17, 27]. Although the reason for this bell-shaped curve in the EPM is still obscure, the same bell-shaped trends have been observed previously in the reports on agmatine [14, 29] and GMP [9], which are endogenous modulatory compounds that produce their anxiolytic-like effects. Most of anxiolytic affect to the amount of neurotransmitters in the synaptic cleft. Although we did not measure the neurotransmitters contents in the synaptic cleft, we assumed that quercetin could also influence on neurotransmitters in the synaptic cleft. Therefore, we consider that those bell-shaped dose-dependent manners for quercetin in the present studies might be resulted from its influences on neurotransmitters and receptors. Further studies are needed to clarify these issues.

In the present study, we found that quercetin exerts anxiolytic activity that confirmed by the fact that quercetin administration increases the time spent in open arm in elevated-plus maze test and the number of head dipping in hole-board test. This effect of quercetin was blocked by TACA, suggesting that the anxiolytic effect of quercetin is mediated by $\mathrm{GABA}_{\mathrm{A}-\mathrm{p}}$ receptors. However, administration quercetin did not show any hypoactivities and myorelaxation. Therefore, quercetin seems to be developed as a prominent anxiolytic drug with no side effect.

\section{Acknowledgement}

This work was supported by the research grant of Jeju National University in 2011.

\section{References}

1. Association, A. P. 1994. Diagnostic and Statistical Manual of Mental Disorders, pp. 393-444, 4th eds., American Psychiatric Association. Washington, D.C. USA.

2. Bennet, D. and Kim, S. 2013. Impedance-based cell culture platform to assess light-induced stress changes with antagonist drugs using retinal cells. Anal Chem 85, 4902-4911.

3. Bhutada, P., Mundhada, Y., Bansod, K., Ubgade, A., Quazi, M., Umathe, S. and Mundhada, D. 2010. Reversal by quercetin of corticotrophin releasing factor induced anxiety- and depression-like effect in mice. Prog Neuropsy chopharmacol Biol Psychiatry 34, 955-960.

4. Bonetti, E. P., Pieri, L., Cumin, R., Schaffner, R., Pieri, M., Gamzu, E. R., Muller, R. K. and Haefely, W. 1982. Benzodiazepine antagonist Ro 15-1788: neurological and behavioral effects. Psychopharmacology (Berl) 78, 8-18.

5. Bourin, M., Fiocco, A. J. and Clenet, F. 2001. How val- uable are animal models in defining antidepressant activity? Human Psychopharmacology 16, 9-21.

6. Chebib, M. 2004. GABAC receptor ion channels. Clin Exp Pharmacol Physiol 31, 800-804.

7. Chirumbolo, S. 2012. Quercetin in Cancer Prevention and Therapy. Integr Cancer Ther 12, 97-102.

8. Dawson, G. R. and Tricklebank, M. D. 1995. Use of the elevated plus maze in the search for novel anxiolytic agents. Trends Pharmacol Sci 16, 33-36.

9. Eckeli, A. L., Dach, F. and Rodrigues, A. L. 2000. Acute treatments with GMP produce antidepressant-like effects in mice. Neuroreport 11, 1839-1843.

10. Fabene, P. F., Mariotti, R., Navarro Mora, G., Chakir, A. and Zancanaro, C. 2008. Forced mild physical training-induced effects on cognitive and locomotory behavior in old mice. J Nutr Health Aging 12, 388-390.

11. Flores-Gracia, C., Nuche-Bricaire, A., Crespo-Ramirez, M., Miledi, R., Fuxe, K. and Perez de la Mora, M. 2010. GABA(A) rho receptor mechanisms in the rat amygdala and its role in the modulation of fear and anxiety. Psychopharmacology (Berl) 212, 475-484.

12. Korpi, E. R., Grunder, G. and Luddens, H. 2002. Drug interactions at GABA(A) receptors. Prog Neurobiol 67, 113-159.

13. Korte, S. M. and De Boer, S. F. 2003. A robust animal model of state anxiety: fear-potentiated behaviour in the elevated plus-maze. Eur J Pharmacol 463, 163-175.

14. Li, Y. F., Gong, Z. H., Cao, J. B., Wang, H. L., Luo, Z. P. and Li, J. 2003. Antidepressant-like effect of agmatine and its possible mechanism. Eur J Pharmacol 469, 81-88.

15. Lister, R. G. 1987. The use of a plus-maze to measure anxiety in the mouse. Psychopharmacology (Berl) 92, 180-185.

16. Lydiard, R. B. 2003. The role of GABA in anxiety disorders. J Clin Psychiatry 64 Suppl 3, 21-27.

17. Moreira, F. A., Aguiar, D. C. and Guimaraes, F. S. 2006. Anxiolytic-like effect of cannabidiol in the rat Vogel conflict test. Prog Neuropsychopharmacol Biol Psychiatry 30, 1466-1471.

18. Olsen, R. W. and Sieghart, W. 2008. International Union of Pharmacology. LXX. Subtypes of gamma-aminobutyric acid(A) receptors: classification on the basis of subunit composition, pharmacology, and function. Update. Pharmacol Rev 60, 243-260.

19. Pellow, S. and File, S. E. 1986. Anxiolytic and anxiogenic drug effects on exploratory activity in an elevated plusmaze: a novel test of anxiety in the rat. Pharmacol Biochem Behav 24, 525-529.

20. Ressler, K. J. and Nemeroff, C. B. 2001. Role of norepinephrine in the pathophysiology of neuropsychiatric disorders. CNS Spectr 6, 663-666,670.

21. Sadock, B. J., Kaplan, H. I. and Sadock, V. A. 2007. Kaplan and Sadock's Synopsis of Psychiatry, pp. 1470, 10th, Lippincott Williams \& Wilkins. Philadelphia.

22. Sandford, J. J., Argyropoulos, S. V. and Nutt, D. J. 2000. The psychobiology of anxiolytic drugs. Part 1: Basic neurobiology. Pharmacol Ther 88, 197-212.

23. Scholze, P., Ebert, V. and Sieghart, W. 1996. Affinity of various ligands for GABAA receptors containing alpha 4 beta 
3 gamma 2, alpha 4 gamma 2, or alpha 1 beta 3 gamma 2 subunits. Eur J Pharmacol 304, 155-162.

24. Shekhar, A. 1993. GABA receptors in the region of the dorsomedial hypothalamus of rats regulate anxiety in the elevated plus-maze test. I. Behavioral measures. Brain Res 627, 9-16.

25. Takeda, H., Tsuji, M. and Matsumiya, T. 1998. Changes in head-dipping behavior in the hole-board test reflect the anxiogenic and/or anxiolytic state in mice. Eur J Pharmacd 350, 21-29.

26. Toumi, M. L., Merzoug, S., Baudin, B. and Tahraoui, A. 2013. Quercetin alleviates predator stress-induced anxiety-like and brain oxidative signs in pregnant rats and immune count disturbance in their offspring. Pharmacol
Biochem Behav 107, 1-10.

27. Vaidya, A. H., Rosenthal, D. I., Lang, W., Crooke, J. J., Benjamin, D., Ilyin, S. E. and Reitz, A. B. 2005. Oral buspirone causes a shift in the dose-response curve between the elevated-plus maze and Vogel conflict tests in Long-Evans rats: relation of brain levels of buspirone and 1-PP to anxiolytic action. Methods Find Exp Clin Pharmacol 27, 245-255.

28. Wittchen, H. U. and Hoyer, J. 2001. Generalized anxiety disorder: nature and course. J Clin Psychiatry 62 Suppl 11, 15-19; discussion 20-11.

29. Zomkowski, A. D., Hammes, L., Lin, J., Calixto, J. B., Santos, A. R. and Rodrigues, A. L. 2002. Agmatine produces antidepressant-like effects in two models of depression in mice. Neuroreport 13, 387-391.

\section{초록 : Quercetin의 항불안 효과: GABA 신경계를 중심으로}

정지욱 ${ }^{1} \cdot$ 이승헌 ${ }^{2 *}$

( ${ }^{1}$ 대구한의대학교 한방산업대학 한약재약리학과, ${ }^{2}$ 제주대학교 해양과학대학 해양생명과학과)

이 연구의 목적은 mice를 이용하여 elevated plus-maze (EPM) test와 hole-board test를 통해 quercetin의 잠재 적인 항불안 작용을 확인하고자 함이다. Quercetin을 $1.25,2.5,5$ 나 $10 \mathrm{mg} / \mathrm{kg}$ 의 용량으로 각각 행동시험을 측정하 기 1 시간 전에 ICR mice에 경구투여하였다. 대조군은 동일한 양의 $10 \%$ Tween 80 을 투여하였고 양성 대조군으로 buspirone $2 \mathrm{mg} / \mathrm{kg}$ 을 투여하였다. Quercetin을 단회 투여하여 EPM test를 실시한 결과, $5 \mathrm{mg} / \mathrm{kg}$ 용량에서 open $\mathrm{arm}$ 에 머문 시간 및 진입한 횟수의 백분율이 control group과 비교하여 통계적으로 유의성 있게 증가하였다 ( $p \times 0.05)$. 또한 quercetin을 투여하여 hole-board test를 실시한 결과, $5 \mathrm{mg} / \mathrm{kg}$ 용량에서 구멍에 머리를 넣은 횟수 가 control group과 비교하여 통계적으로 유의성 있게 증가하였다( $p<0.05)$. 또한 quercetin와 flumazenil $\left(\mathrm{GABA}_{\mathrm{A}}\right.$ antagonist), WAY-100635 (5- $\mathrm{HT}_{1 \mathrm{~A}}$ antagonist) 또는 trans-4-aminocrotonic acid (GABA $\mathrm{A}_{\mathrm{A}-\mathrm{p}}$ agonist)를 병용투여하 여 elevated plus-maze를 실험을 하여 신경계와의 관계를 확인한 결과, trans-4-aminocrotonic acid에서만 quercetin의 항불안 작용이 차단되었음을 확인 할 수 있었다. 결론적으로, 본 연구의 결과에서 quercetin이 elevated plus-maze 및 hole-board test, horizontal wire test, open field test를 통하여 locomotor activity 및 근육이완이나 진정 등의 부작용이 없으면서 우수한 항불안 작용을 가지는 소재라고 생각되며 이러한 작용이 특히 GABA 신경 계와 관련이 있음을 시사하고 있다. 